\title{
SOSIALISASI PELUANG DAN TANTANGAN BAGI LULUSAN S1 PETERNAKAN DALAM MENGHADAPI DUNIA KERJA DI SMKN 1 KUOK
}

\author{
Maulina Novita ${ }^{1}$, D. Ramdani ${ }^{2}$, U. Habiyah ${ }^{3}$ \\ ${ }^{1,2,3)}$ Program Studi Peternakan, Fakultas Teknik, Universitas Pahlawan Tuanku Tambusai \\ e-mail: maulinanovita1@gmail.com
}

\begin{abstract}
Abstrak
Memasuki era globalisasi, tantangan yang dihadapi generasi muda semakin berat. Salah satunya adalah persaingan dalam dunia kerja yang membuat mereka kurang siap untuk menghadapinya. Globalisasi adalah pertumbuhan yang cepat atas keterhubungan dan ketergantungan antara negaranegara yang ada di dunia dalam hal keuangan dan perdagangan. Perkembangan ilmu pendidikan dan teknologi serta tuntutan globalisasi secara bersama-sama membuat semakin berat dalam mempersiapkan sumber daya manusia yang unggul. Ilmu Peternakan mempelajari semua kegiatan terkait peternakan. Mahasiswa pada program studi ini nantinya juga akan mempelajari tentang teknologi produksi, teknologi pakan, teknologi pengolahan, serta manajemen dan perencanaan usaha. Hasil kegiatan-kegiatan yang dilakukan pada pengabdian masyarakat di SMKN 1 Kuok adalah sebagai berikut. (1) Pemberitahuan pada sekolah mitra yang akan dijadikan lokasi pengabdian dan Dinas Pendidikan terkait. Pelaksanaan tahap ini didahului dengan mengirim surat pemberitahuan kepada pihak sekolah dan dinas pendidikan terkait. Setelah itu dilakukan koordinasi untuk membahas teknis pelaksanaan kegiatan. (2) Sosialisasi program pengabdian, sosialisasi dilakukan dengan melakukan koordinasi dan menyampaikan pemberitahuan secara tertulis kepada kelompok kerja guru SMKN 1 Kuok (3) Penyusunan program sosialisasi Berdasarkan hasil identifikasi, hasil analisis permasalahan yang ada, hasil analisis kebutuhan, dan hasil analisis potensi sekolah, selanjutnya disusun program sosialisasi. Sosialisasi yang diberikan berupa sosialisasi bagi siswa SMKN 1 Kuok. Kesimpulan siswa-siawa mengetahui apa itu jurusan peternakan dan mengetahui apasaya peluang lulusan sarjana peternakan.
\end{abstract}

Kata kunci: Sosialisasi, Prodi Peternakan, Sarjana Peternakan.

\begin{abstract}
Entering the era of globalization, the challenges faced by the younger generation are getting tougher. One of them is competition in the world of work which makes them less prepared to face it. Globalization is the rapid growth of connectedness and dependence between the countries of the world in terms of finance and trade. The development of education and technology and the demands of globalization together make it increasingly difficult to prepare superior human resources. Animal Science studies all activities related to animal husbandry. Students in this study program will also learn about production technology, feed technology, processing technology, and business management and planning. The results of the activities carried out in community service at SMKN 1 Kuok are as follows. (1) Notification to partner schools that will be used as service locations and the relevant Education Office. The implementation of this stage is preceded by sending a notification letter to the school and the relevant education office. After that, coordination was carried out to discuss the technical implementation of activities. (2) Socialization of service programs, socialization is carried out by coordinating and submitting written notifications to the working group of teachers at SMKN 1 Kuok (3) Preparation of socialization programs Based on the results of identification, analysis of existing problems, results of needs analysis, and results of school potential analysis, then a socialization program is prepared. The socialization provided was in the form of socialization for students of SMKN 1 Kuok. In conclusion, students know what a major in animal husbandry is and know if I have a chance to graduate from a bachelor's degree in animal husbandry.
\end{abstract}

Keywords: Socialization, Animal Husbandry Study Program, Bachelor of Animal Husbandry. 


\section{PENDAHULUAN}

Memasuki era globalisasi, tantangan yang dihadapi generasi muda semakin berat. Salah satunya adalah persaingan dalam dunia kerja yang membuat mereka kurang siap untuk menghadapinya. Globalisasi adalah pertumbuhan yang cepat atas keterhubungan dan ketergantungan antara negara-negara yang ada di dunia dalam hal keuangan dan perdagangan. Perkembangan ilmu pendidikan dan teknologi serta tuntutan globalisasi secara bersama-sama membuat semakin berat dalam mempersiapkan sumber daya manusia yang unggul.

Menurut Rivai Veithzal (2004:17) "hal terpenting untuk menghadapi era globalisasi adalah kesiapan kerja dalam diri seseorang". Kesiapan kerja sama halnya dengan mempersiapkan sumber daya manusia. Sumber Daya Manusia adalah seseorang yang siap, mau dan mampu memberi sumbangan terhadap usaha pencapaian tujuan organisasi. Dimana kesiapan kerja umumnya dikembangkan dari jenjang pendidikan. Sistem pendidikan Indonesia dibagi dalam beberapa jenjang. Salah satunya adalah Jenjang Perkuliahan Strata-1. Jenjang perkuliahan ini adalah salah satu peranan penting dalam kontribusi mempersiapkan sumber daya manusia untuk memasuki dunia kerja

Perguruan Tinggi merupakan jenjang pendidikan yang bertanggung jawab dalam menyiapkan SDM yang memiliki kemampuan, keterampilan, dan keahlian yang siap terjun di dunia kerja, tetapi hingga saat ini belum dapat terwujud secara optimal. Dari uraian diatas dapat diketahui bahwa belum terserapnya lulusan sarjana di dalam dunia kerja sebagian besar dipengaruhi oleh kesiapan kerja dari sarjana tersebut. Kesiapan kerja yang rendah menyebabkan sarjana belum memiliki kemauan serta kemampuan untuk bekerja.

Kesiapan kerja yang dimaksud dalam penelitian ini adalah kesiapan dari segi softskill dan mental dari diri mahasiswa untuk bersaing di dunia kerja. Kesiapan soft skill dan kematangan mental ini dapat dipengaruhi oleh pengalaman praktik kerja yang telah dilakukan oleh mahaiswa. Menurut Agus Fitriyanto (2006 : 9) "Kesiapan Kerja adalah kondisi yang menunjukkan adanya keseerasian antara kematangan fisik, mental serta pengalaman sehingga individu mempunyai kemampuan untuk melaksanakan suatu kegiatan tertentu dalam hubungannya dalam pekerjaan". Kesiapan kerja memiliki beberapa faktor yang mempengaruhinya, baik faktor dalam dirinya (internal)maupun faktor dari luar (eksternal). Menurut Slameto (2010 : 67) ada tiga kondisi kesiapan kerja yaitu: "(1) keadaan jasmani, mental dan emosional (2) keperluan, motif dan maksud (3) kemahiran dan ilmu yang dimiliki”. Disebutkan pula bahwa pengalaman dapat menimbulkan pengaruh positif terhadap kesiapan kerja

\section{METODE}

Metode dalam sosialisasi ini: a) Melakukan koordinasi dengan Kepala Sekolah SMKN 1 Kuok, b) Melakukan penyusunan materi sosialisasi peluang dan tantangan bagi lulusan S1 peternakan menghadapi dunia kerja, c) Observasi dan evaluasi, d) Refleksi.

\section{HASIL DAN PEMBAHASAN}

Sosialisasi jurusan S1 Peternakan di SMKN 1 Kuok dilaksanakan pada tanggal 22 Maret 2019, bertempat di lapangan sekolah. Tujuan kegiatan pengabdian masyarakat ini adalah untuk memberikan pengetahuan dan informasi tentang peluang dan tantangan bagi lulusan S1 Peternakan dalam menghadapi dunia kerja kepada siswa-siswa. Dengan demikian diharapkan siswa-siswa mampu lebih mengetahui jurusan S1 Peternakan yang ada di Universitas Pahlawan Tuanku Tambusai sehingga dapat menghadapi dunia kerja. Tidak banyak siswa SMKN 1 Kuok mengetahui apa itu jurusan S1 Peternakan berupa apa saja peluangnya di dalam dunia kerja. Dengan demikian, sosialisasi yang dibuat sesuai dengan yang direncanakan dalam program pengabdian masyarakat. Hal ini dikarenakan siswa sekolah masih ingin melanjutkan kuliahnya dan memberikan sosialisasi kepada guru dan siswa untuk menggunakannya terlebih dahulu.

Setelah siswa SMKN 1 Kuok mengetahui tentang peluang lulusan S1 Peternakan, maka langkah selanjutnya ialah memberikan sosialisasi kepada guru dan siswa-siswa. Sosialisasi dilakukan secara bergelombang karena keterbatasan instruktur dan sarana untuk praktik. Dalam kegiatan sosialisasi yang dijadikan satu dengan kegiatan program pengabdian masyaraka, jumlah siswa yang mengikuti sosialisasi sebanyak 100 orang anak kelas 3 yang akan lulus sekolah. Untuk 
siswa yang belum mengikuti sosialisasi bulan maret, maka mereka akan mendapatkan sosialisasi pada gelombang selanjutnya. Materi yang disampaikan dalam sosialisasi terdiri dari pengenalan tentang peluang dan tantangan lulusan S1 Peternakan dalam menghadapi dunia kerja, mengadakan sesi diskusi dan permainan-permainan yang mendapatkan hadiah.

Pada saat sosialisai banyak mataeri dan informasi yang disampaikan kepada siswa, sehingga siswa lebih banyak mengetahu tentang jurusan serta lulusan S1 Peternakan. Sebelum diadakan sosialisasi masih bingung akan melanjutkan kuliah atau tidak, serta jika melanjutkan kuliah mereka juga bingung jurusan apa yang cocok untuk mereka. Banyak sekali pertanyaan serta diskusi dari siswa yang begitu antusias terhadap pelaksanaan sosialisai tersbeut.

\section{SIMPULAN}

Kesimpulan dari Sosialisasi tentang peluang dan tantangan bagi lulusan S1 peternakan dalam menghadapi dunia kerja di SMKN 1 Kuok ialah:

1. Siswa-siswa mengetahui apa itu jurusan Peternakan

2. Siswa-siswa yang mengikuti sosialisasi telah dapat apa saja peluang mereka dan SARAN tantangan mereka bagi lulusan S1 peternakan dalam menghadapi dunia kerja.

Saran yang dapat kami sampaikan setelah melakukan kegiatan Pengabdian kepada Masyarakat di SMKN 1 Kouk adalah sebagi berikut:

1) Siswa-siswa SMKN 1 Kuok perlu sering diberi sosialisasi mengenai menghadapi dunia kerja.

2) Siswa-siswa SMKN 1 Kuok perlu sering diberi sosialisasi mengenai dunia kuliah terutama jurusan S1 Peternakan.

\section{UCAPAN TERIMA KASIH}

Penulis mengucapkan terima kasih kepada LPPM Universitas Pahlawan Tuanku Tambusai yang telah memberi dukungan financial dan kepada SMKN 1 Kuok terhadap pengabdian ini.

\section{DAFTAR PUSTAKA}

Rivai, Veithzal .2004. Manajemen Sumber Daya Manusia Untuk Perusahaan. Cetakan Pertama. PT. Raja Grafindo. Jakarta.

Direktorat Pembinaan SMK. 2008. Garis-Garis Besar Besar Program Pembinaan SMA Tahun 2008. Jakarta : Dirjen Manajemen Pendidikan Dasar dan Menengah

Agus, Fitri Yanto. (2006). Ketidak Siapan Memasuki Duia Kerja Karena Pendidikan. Jakarta: Dinamika Cipta.

Slameto. (2010). Belajar dan Faktor- faktor yang Mempengaruhinya. Jakarta: Rineka Cipta. 